\title{
Sucrose responsiveness and behavioral plasticity in honey bees (Apis mellifera)
}

\author{
Ricarda SCHEINER ${ }^{\text {a*}}$, Robert E. PAGE ${ }^{\mathrm{b}}$, Joachim ERBER $^{\mathrm{a}}$ \\ a Institut für Ökologie, Technische Universität Berlin, Franklinstr. 28/29, 10587 Berlin, Germany \\ $\mathrm{b}$ Department of Entomology, University of California, Davis, CA 95616, USA
}

(Received 8 August 2003; revised 15 November 2003; accepted 15 December 2003)

\begin{abstract}
This review will focus on the relationships between sensory responses of bees and behavior. Sensory responsiveness constrains individual foraging plasticity and skews collective foraging decisions of colonies. We will concentrate on pollen, nectar, and water foraging behavior and will show that differences in the sucrose responsiveness of bees correlate with different behavioral roles, which supports the response threshold model of division of labor. We will also show how a colony's "allocation" of foragers into foraging roles results from individual differences in responsiveness to task-related stimuli and discuss hypotheses on the behavioral relevance of these differences.
\end{abstract}

behavioral plasticity / sucrose responsiveness / foraging behavior / collective decision / response threshold model

\section{INTRODUCTION}

Individual honey bees respond to stimuli resulting in behavior. Sugar is one of the most important stimuli for honey bees (Apis mellifera L.), because it is their main source of carbohydrates, results in foraging and recruitment behavioral responses (see Seeley, 1995 for review), and is a reinforcement stimulus for instrumental and operant associative learning (see Menzel and Müller, 1996 for review). Nectar from a great variety of flowers is collected by foragers and processed into honey in the colony. The main components of nectar are sucrose, glucose and fructose (Beutler, 1935; Seeley, 1995; Corbet, 2003), but bees prefer sucrose to most other naturally occurring sugars (Barker and Lehner, 1974). Sucrose does not only play a key role in nutrition. It serves as reward for foragers when they learn the characteristics of floral sources during forag- ing and is an important determinant for many foraging-related decisions.

The sucrose concentration of a nectar source correlates with the size of the crop-load of a forager (von Frisch, 1965; Pflumm, 1969; Schmid-Hempel et al., 1985; Núñez and Giurfa, 1996) and affects the speed of nectar intake, the decision to return to a nectar source and the time between foraging bouts (Núñez, 1966; Pflumm, 1969; Greggers et al., 1993). The decision of individual foragers to inform their hive mates about this source by performing a recruitment dance also depends on the sucrose concentration of the floral source (von Frisch, 1965; Raveret-Richter and Waddington, 1993; Seeley, 1995; Waddington, 1997). The sucrose concentration of a feeder also affects the transfer rate of sucrose solution during trophallaxis between a returning forager and a nectar receiver bee (Farina and Núñez, 1991; Roces and Blatt,

\footnotetext{
* Corresponding author: Ricarda.Scheiner-Pietsch@mailbox.TU-Berlin.de
} 
1999; Tezze and Farina, 1999). These examples demonstrate that foragers evaluate the sugar concentration of a food source directly and use this information to "decide" whether to exploit this food source and to recruit more bees to this location. The collective result of these activities based on individual evaluation of the sugar resource is a shift in the allocation of foragers among the different available foraging patches, and changes the quantity and quality of a colony's nectar intake.

Pollen is crucial for colonies as the source of protein for brood rearing. The pollen foraging effort of a colony must constantly be adapted to the requirements of the brood and, like foraging for nectar, must adapt constantly to a rapidly changing foraging environment. Pheromones produced by larvae release pollen foraging behavior (Pankiw et al., 1998) while stored pollen inhibits pollen foraging (Fewell and Winston, 1992; Dreller et al., 1999; Dreller and Tarpy, 2000). The quality of the pollen in the field also affects foraging and recruitment behavior (Waddington et al., 1998; Fewell and Page, 2000). Nectar and pollen foraging are not independent. Bees that collect larger loads of pollen collect smaller loads of nectar (Hunt et al., 1995; Page et al., 2000), and vice versa. Therefore, the total loading capacity of a bee sets a constraint on individual foraging. Shifts in responses to foraging stimuli that affect one resource necessarily affect the responses to the other. Shifts in the colony allocation of foraging effort to one resource necessarily affect the intake rates of the other. The collective response of a colony is therefore constrained by these relationships. In order to better understand the collective behavior of a foraging colony we must understand the relationships between individual worker responses to stimuli and their foraging and recruitment behavior. What are the mechanisms that govern foraging and recruitment decisions? A widely accepted hypothesis regards "threshold models" as the basis for division of labor in social insects (Calderone and Page, 1988; Robinson and Page, 1989; Robinson, 1992; Bonabeau et al., 1996; Theraulaz et al., 1998; Arathi and Spivak, 2001; Beshers and Fewell, 2001). According to this view, the bees of a colony differ in their response thresholds to stimuli associated with certain tasks. Once the inten- sity of a task-related stimulus exceeds the response threshold of an individual, the bee starts performing the associated task. Subgroups of a honey bee colony which start engaging in a certain task will therefore have a similar response threshold for a certain stimulus associated with that task and will constitute a task group. Sucrose is an important stimulus for honey bee foraging behavior. Variation in responsiveness to sucrose has been found to be related to foraging behavioral decisions and learning. Therefore, this review will focus on responsiveness to sucrose and individual behavior with the understanding that collective foraging responses of colonies are derived from the interactions of the individuals (Page and Mitchell, 1998).

\section{MEASURING SUCROSE RESPONSIVENESS}

The sucrose responsiveness of honey bees has been measured since the early nineteen twenties by various authors using different paradigms, but how responsiveness to sucrose was measured and defined varies considerably from author to author. Von Frisch (1927) measured the "acceptance threshold" of groups of free-flying bees at feeders whose sucrose concentrations were varied. The acceptance threshold was the lowest concentration which was consumed by at least a few bees. Response thresholds of individuals have been determined by applying different sucrose concentrations to the antennae of restrained bees (Fig. 1, inset). When the antenna of a bee is touched with a droplet of sucrose solution of sufficient concentration, the bee reflexively extends its proboscis - a behavior that is referred to as proboscis extension response (PER). Kunze (1933) and Marshall (1935) regarded the lowest sucrose concentration eliciting proboscis extension as the individual response threshold of a bee. In more recent years, Page et al. (1998) defined the sucrose response threshold of an individual as the lowest sucrose concentration which the bee can distinguish from water. The sucrose response threshold of a group - their "empirical threshold" - is the sucrose concentration at which the group response to sucrose statistically exceeds the group response to water. This 


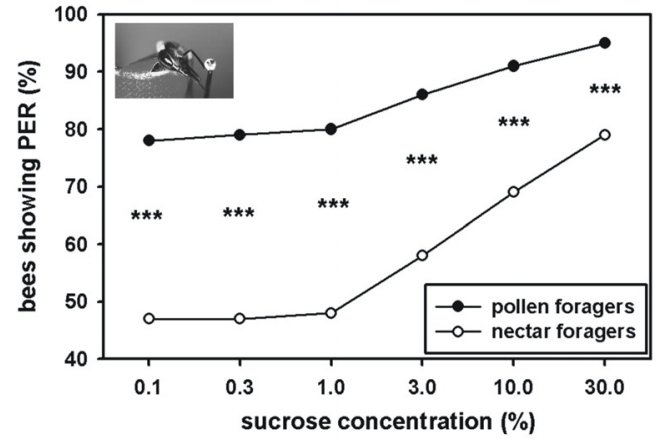

Figure 1. Sucrose-concentration response curves of pollen and nectar foragers tested on their return to the hive. Individual foragers were restrained and tested for their responsiveness to 6 different sucrose concentrations ranging from $0.1 \%$ to $30 \%$ sucrose on a logarithmic scale. At each antennal stimulation with sucrose (inset) the occurrence of proboscis extension was noted. A significantly greater percentage of pollen foragers responded with proboscis extension at each sucrose stimulation (***: $P=0.05, \mathrm{n}_{\text {pollen }}=342, \mathrm{n}_{\text {nectar }}=353$, twotailed Fisher Exact Probability Test). Data taken from Scheiner et al. (2003a).

group response threshold depends on the group's average response threshold, the group variance in response thresholds and sample size (Page et al., 1998; Pankiw and Page, 1999, 2000). An alternative measure of sucrose responsiveness which has been used in recent years is the "sucrose response score" (SRS). This score comprises the total number of proboscis responses to a series of sucrose concentrations (Pankiw et al., 2001; Pankiw and Rubink, 2002; Scheiner et al., 2002, 2003a; Pankiw, 2003; Page et al., submitted). The "gustatory response score" (GRS), which has also been used frequently, represents the total number of proboscis responses to water and a series of sucrose concentrations (Scheiner et al., 1999; Pankiw and Page, 2001; Scheiner et al., 2001a, b, c, 2003b). Gustatory and sucrose response scores correlate with individual sucrose response thresholds, because once a bee responds to a certain sucrose concentration, it usually continues to respond to higher sucrose concentrations. Responsiveness to water stimuli which are applied between different sucrose stimuli correlates with sucrose responsiveness (Page et al., 1998).
The variety of terms which have been employed for describing the responses to gustatory stimuli in honey bees is confusing. We have therefore decided to use "sucrose responsiveness" as a general term which describes the responses of bees to sucrose solutions of different concentrations. Bees with a high sucrose responsiveness show proboscis extension to low sucrose concentrations, such as $0.1 \%(0.003 \mathrm{M})$ or $1 \%(0.03 \mathrm{M})$. Sometimes these bees even respond to water. Individuals with low sucrose responsiveness only respond to high sucrose concentrations, such as $30 \%$ $(0.9 \mathrm{M})$ or $50 \%(1.5 \mathrm{M})$ sucrose.

\section{THE DECISION TO INITIATE FORAGING BEHAVIOR}

The colony's need for nectar is great throughout the season, because it serves as a food reserve for the wintertime. Accordingly, nectar collection is high throughout the foraging season, provided the colony has enough space for honey storage. The need for pollen, which is mainly consumed by the brood, changes drastically throughout the year. When the amount of brood is high, particularly in spring and summer, the colony intensifies its pollen collecting behavior. How do potential pollen foragers inform themselves about the amount of brood in a colony and adapt their foraging behavior accordingly?

Honey bees can estimate the amount of brood in a colony by sensing the concentration of an odor produced by the brood (see Pankiw, 2004, this issue). The concentration of this brood pheromone increases with increasing numbers of larvae, which serves as a signal for potential foragers to start pollen foraging (Barker, 1971; Free, 1987; Fewell and Winston, 1992; Eckert et al., 1994; Pankiw et al., 1998; Dreller et al., 1999; Dreller and Tarpy, 2000; Barron et al., 2002). According to the response threshold model, bees with low response thresholds to brood pheromone should decide to start pollen foraging when the intensity of brood odor is low. An increase in the concentration of brood pheromone should soon exceed the response thresholds of other bees and thus result in increased pollen foraging. There is abundant evidence that brood pheromone can trigger pollen foraging 
(Barker, 1971; Free, 1987; Fewell and Winston, 1992; Eckert et al., 1994; Pankiw et al., 1998; Dreller et al., 1999; Dreller and Tarpy, 2000; Barron et al., 2002), but individual response thresholds to brood pheromone are very difficult to measure. However, it has been shown that brood pheromone can modulate sucrose responsiveness (Pankiw and Page, 2001), and sucrose responsiveness increases with age (Pankiw and Page, 1999). Newly emerged bees with higher responsiveness to sucrose initiate foraging earlier in life (Pankiw, 2003), suggesting that responsiveness to sucrose may correlate with responsiveness to brood pheromone. It is interesting to note that the link between sucrose responsiveness and the age of onset of foraging behavior results in the earlier onset of foraging in pollen foragers. It is still not known if modulating sucrose responsiveness by exposure to brood pheromone results in shifts in individual or collective foraging behavior.

\section{THE DECISION TO COLLECT POLLEN, NECTAR, OR WATER}

Sucrose responsiveness correlates with the decision to collect pollen, nectar, or water. Pollen foragers of a honey bee colony are on average more responsive to sucrose than nectar foragers in most weeks of a foraging season (Scheiner et al., 2003a). Pollen foragers tested after returning from a foraging trip display a higher sucrose responsiveness than nectar foragers (Fig. 1; Page et al., 1998; Scheiner et al., 2001b, 2003a). Sucrose responsiveness of newly emerged bees correlates with their foraging behavior that is initiated 2-3 weeks later (Pankiw and Page, 2000; Pankiw, 2003) Water foragers are the most responsive followed by pollen foragers, bees that collect both nectar and pollen, nectar foragers, and the least responsive bees are most likely to return empty (Fig. 2; Pankiw and Page, 2000). Nectar foragers that are more responsive to sucrose collect nectar with lower sugar concentrations than those that are less responsive (Pankiw and Page, 2000; Pankiw, 2003). It is assumed that they have such a low sucrose responsiveness that they do not find an acceptable food source. The physiological basis for the correlation between sucrose response and

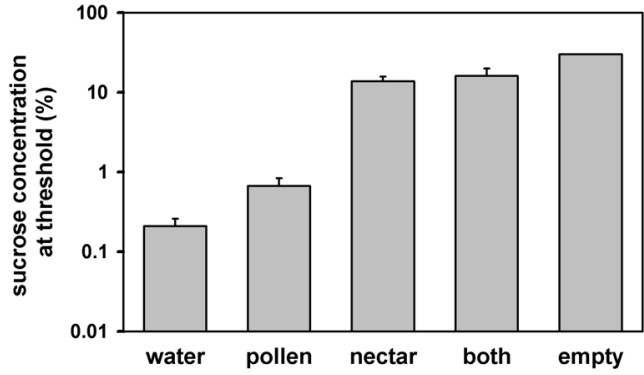

Figure 2. Sucrose responsiveness correlates with foraging tasks. Returning foragers were caught and restrained to measure their sucrose responsiveness individually. In that experiment, individual response thresholds to sucrose were estimated. High response thresholds correspond to low sucrose response scores. Low response thresholds correspond to high sucrose response scores. Water and pollen foragers were the most responsive bees and displayed the lowest response thresholds. Foragers collecting nectar, pollen or nectar, and bees returning empty from their foraging trips displayed a low sucrose responsiveness. Their estimated response threshold was very high. Means and standard errors are displayed. Figure modified after Pankiw and Page (2000).

foraging behavior is unclear. It is unlikely that sucrose responsiveness is causally linked to foraging decisions. It is more likely that the correlations of sucrose responsiveness with the different foraging traits are consequences of indirect common causal factors affecting the sensory response system of bees and foraging behavior. Bees with high sucrose responsiveness are generally more responsive to stimuli in other sensory modalities. Bees with high sucrose responsiveness are also more responsive to pollen (gustatory; Fig. 3A), citral (olfactory; Fig. 3B), and to low intensities of light (visual; Erber, personal observation) than bees with low sucrose responsiveness. These results support the hypothesis that pollen foragers are also more responsive than nectar foragers to chemical stimuli like brood pheromone. So far, there has been no experimental evidence in the bee that the sensitivities of the sensory systems for different modalities can be tuned independently. High sensitivity for one modality is apparently correlated with high sensitivity for other modalities. The physiological basis of these findings is still unclear. We assume that the same neuromodulators or neurohormones control the 

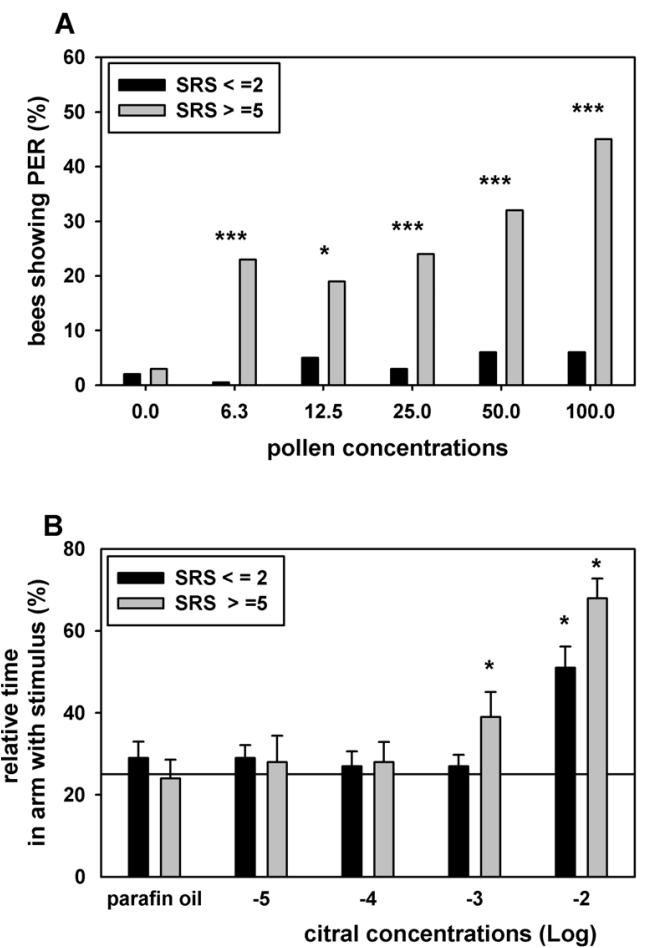

sensitivities of different sensory systems in the periphery and in the central nervous system. The release of these neuroactive substances probably affects many different subsystems simultaneously.

\section{SUCROSE RESPONSIVENESS AND DECISIONS IN ASSOCIATIVE LEARNING}

During their foraging trips, bees learn the colors, odors, shapes and structures of floral sources. Foragers have to evaluate the quality of the nectar or pollen and must then decide whether to exploit a food source or not. If they find the food source acceptable, they need to
Figure 3. Sucrose responsiveness correlates with responsiveness to pollen and citral. A. Honey bee foragers were restrained in holders and their antennae were stimulated with the same 6 sucrose concentrations as shown in Figure 1. Afterwards, the antennae were stimulated with different concentrations of almond pollen and cellulose of the same grain size. The almond pollen was collected directly from flowers. Bees were separated in groups with low or high sucrose response scores (SRS). At most pollen concentrations the percentage of bees responding with proboscis extension was greater in the group of bees with high sucrose responsiveness $(\mathrm{SRS}=5)$ than in bees with low sucrose responsiveness ( $\mathrm{SRS}=2$; *: $P=0.05, * * *: P=0.001, \mathrm{n}_{\mathrm{SRS}}=2=63 . \mathrm{n}_{\mathrm{SRS}}=5=$ 108, two-tailed Fisher Exact Probability Test). B. Honey bee foragers were tested in a four-armed olfactometer for their responsiveness to different concentrations of citral. The abscissa shows the different odor concentrations. The ordinate displays the mean percentage of time spent in the arm containing the odor and the standard errors. The reference line indicates the $25 \%$ level of erratic choice. Bees are grouped as in A. Only individuals which spent at least half of the time outside the central area and thus displayed average walking activity were analyzed. Individuals with a low sucrose responsiveness $(\mathrm{SRS}=2)$ had a high olfactory response threshold and only recognized the odor at the highest concentration $\left(10^{-2}\right)$. Bees with a high sucrose responsiveness ( $\mathrm{SRS}=5$ ) already spent significantly more time in the arm containing a lower odor concentration $\left(10^{-3}\right)$. They displayed a lower olfactory response threshold. The odor concentrations at which bees spent significantly more time in the odor-containing arm are indicated: $*: P=0.05$, two-tailed T-Test). At the highest odor concentration, when both groups recognized the odor, bees with a SRS $=5$ spent significantly more time in the respective arm than the bees with a SRS $=2(P=0.05$, $\mathrm{n}_{\mathrm{SRS}}=5=23, \mathrm{n}_{\mathrm{SRS}}=2=26$; two-tailed T-Test) .

learn the location of it to return for several foraging trips and to possibly recruit other foragers.

In several experiments on olfactory and tactile learning in the laboratory or using free-flying bees it was demonstrated that the sucrose concentration used as reward significantly correlates with associative learning performance (Loo and Bitterman, 1992; Couvillon et al., 1994; Bitterman, 1996; Smith, 1997; Laloi et al., 1999; Scheiner et al., 1999). Bees which received a high-concentrated sucrose solution as reward learned faster than bees receiving a low sucrose concentration. But bees receiving the same sucrose solution as a reward also differed in their learning performance. These differences in associative learning have long 

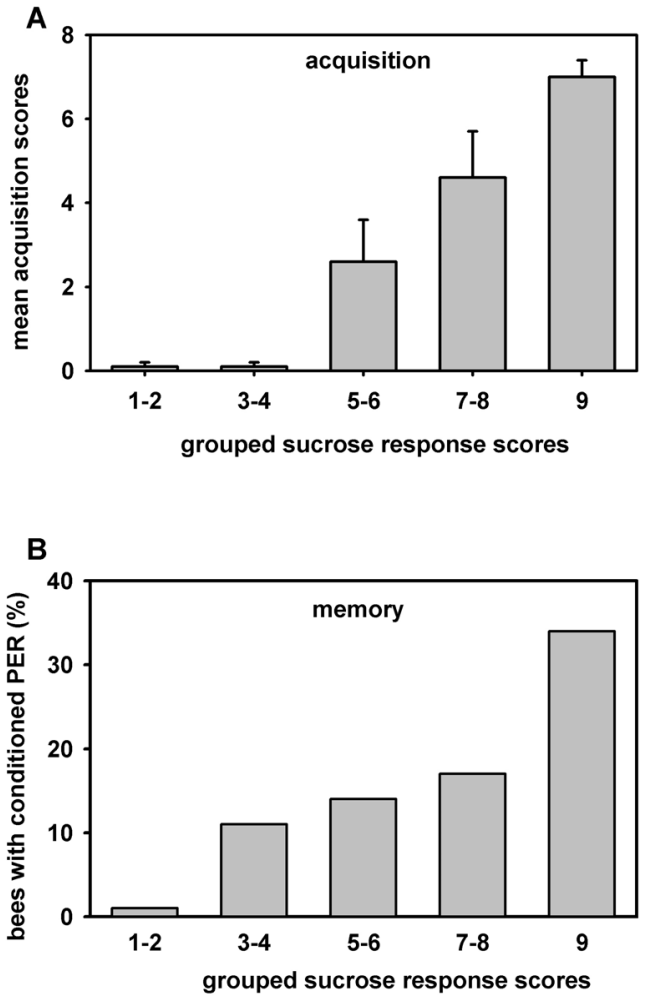

Figure 4. Tactile acquisition and 24-hour memory correlate with sucrose responsiveness. Honey bees in their second week of life were tested for their responsiveness to 9 sucrose concentrations ranging from $1 \%$ to $40 \%$ sucrose on a logarithmic scale. Bees were grouped according to their sucrose response scores and conditioned to a tactile object in 10 trials. A. Mean acquisition scores and standard errors are shown. Acquisition scores comprise the total number of conditioned responses during tactile acquisition. Sucrose response scores correlate positively with acquisition scores $(\mathrm{r}=$ $0.61, P=0.001, \mathrm{n}=99$ ). Bees with high sucrose responsiveness reached a higher acquisition score than bees with low sucrose response scores. B. Correlation between sucrose responsiveness and 24-h memory after tactile conditioning in the same bees. The abscissa shows the grouped sucrose response scores. The ordinate shows the percentage of bees displaying the conditioned response 24 hours after conditioning. Data taken from Scheiner et al. (2001a).

been regarded as a form of unavoidable "noise" in the data. Recently, however, the reason for these learning differences was found. Individual differences in sucrose responsiveness correlate with huge differences in associative learning behavior (Scheiner et al., 1999, 2001a, b, c, 2003a). Individuals with high sucrose responsiveness reach a higher level of acquisition and demonstrate stronger memory than bees with low sucrose responsiveness (Fig. 4, Scheiner et al., 1999, 2001a, b, c, 2003a). As discussed in Scheiner et al. (1999) the difference between the individual responsiveness to sucrose and the sucrose concentration of the reward determines the level of acquisition. Bees with high sucrose responsiveness which receive a lowconcentrated sucrose solution as reward show the same level of acquisition as bees with a low sucrose responsiveness which receive a high-concentrated sucrose solution as reward (J. Erber, R. Scheiner, personal observation).

\section{CONSEQUENCES FOR FORAGING BEHAVIOR}

In contrast to nectar foragers, which receive great sucrose rewards at an accepted food source, it is unclear how pollen foragers are rewarded at a foraging site. The latter possibly reward themselves with very small amounts of nectar or even with the dew on the flower petals. Differences in the sucrose responsiveness of pollen and nectar foragers could be related to the different rewards pollen and nectar foragers receive at a floral source. Pollen foragers are very responsive to sucrose and learn a signal characterizing a food source even with low concentrations of a sucrose reward or water. Laboratory experiments indicate that even water can serve as a reward stimulus in highly responsive bees ( $R$. Scheiner, unpublished data). Nectar foragers are less responsive to sucrose and therefore need higher-concentrated sucrose rewards than pollen foragers to reach the same level of acquisition. Further experiments with free-flying bees will show whether pollen itself can act as a reinforcer.

\section{MODULATION OF SUCROSE RESPONSIVENESS}

Responsiveness to sucrose is not fixed. It varies with season (Scheiner et al., 2003), age (Pankiw and Page, 1999), nutrition, and experience (Pankiw et al., 2001). It is plausible that 
the modulation of sucrose responses of bees within colonies could provide "global" information about the current nutritional status of the colony and affect subsequent foraging and recruitment decisions. Seeley (1995) shows how decisions of nectar foragers to perform recruitment dances are related to the quality of the nectar (sugar solution) they collect. In his study, he determined that different bees had different dance thresholds. If dance thresholds themselves are modulated by the quality and quantity of incoming nectar, then collective decisions may be influenced by information shared by most or all colony members, rather than based completely on localized information.

Pankiw et al. (2001) demonstrated that sucrose responsiveness is modulated by food intake and foraging experience. Nectar returned to the hive is distributed throughout the colony. Pankiw et al. (in press) demonstrated that the sucrose responses of non-foraging bees within a colony modulate with the quality of sugar solution collected by the foragers. Therefore, global information about the current nectar intake of a colony is available for collective decision making, however, it has not been demonstrated if this information is used.

\section{GENETIC DETERMINANTS OF SUCROSE RESPONSIVENESS}

The importance of differences in sucrose responsiveness for collective decision making in the foraging behavior of a colony has been demonstrated. But what determines individual sucrose responsiveness? An important determinant of sucrose responsiveness lies in the genes of a bee. Several quantitative trait loci (QTL) have been found to correlate with sucrose responsiveness and different aspects of foraging behavior. Page and Fondrk (1995) produced genetic strains of honey bees that differed in the amount of surplus pollen they store in the comb and in their pollen foraging behavior. High-strain bees are more likely to collect pollen and are more responsive to sucrose than low-strain bees at all ages (Page et al., 1998; Pankiw and Page, 1999, 2000; Pankiw et al., 2001; Scheiner et al., 2001a, b). Three quantitative trait loci ( $p \ln 1, p \ln 2$ and $p \ln 3$ ) were found to correlate with different aspects of foraging behavior in these strains: the probability to collect pollen or nectar $(p \ln 1$ and pln2: Hunt et al., 1995), the nectar load size ( $p \ln 2$ : Hunt et al., 1995; $p \ln 3$ : Page et al., 2000) and the pollen load size ( $p \ln 2$ : Hunt et al., 1995; pln3: Page et al., 2000). Interestingly, two of these QTL, pln1 and pln3, also correlate with sucrose responsiveness (Chandra et al., unpublished data), suggesting pleiotropic relationships between sucrose responsiveness and foraging behavior (Page and Erber, 2002; Page et al., unpublished data). One of these QTL, pln3, correlates with the age of onset of foraging (Rueppell, personal communication).

Collectively, the results from QTL studies and the studies of the correlations of sucrose responsiveness with foraging behavior suggest that pollen foraging behavior consists of a suite of traits that are linked through common causal factors, including some of the mapped QTL. This suite includes a higher response to olfactory, gustatory, and visual stimuli, early onset of foraging behavior, water foraging, collecting nectar with lower concentrations of sugar, and enhanced associative learning performance. It has been hypothesized that these traits vary together, because they share a common physiological signaling pathway involving cyclic AMP (Page and Erber, 2002).

\section{ACKNOWLEDGEMENTS}

This work was supported by the "Sonderforschungsbereich SFB 515" of the Deutsche Forschungsgemeinschaft by a research grant to the laboratory in Berlin and by providing travel grants which enabled the collaboration between the laboratories in Berlin and Davis. We also wish to thank the Santa Fe Institute for organizing and supporting the "working group on social insects" in the past years. Fruitful discussions and collaborations of this group significantly enhanced our understanding of complex traits of behavior in social insects.

Résumé - Sensibilité de l'Abeille domestique (Apis mellifera) au saccharose et plasticité comportementale. La division du travail dans une colonie d'abeilles (Apis mellifera L.) est un processus complexe qui nécessite à la fois la persistance d'une activité conduisant à la spécialisation et à une compétence accrue, et aussi une plasticité comportementale dans un environnement toujours changeant. Les modifications dans les activités collectives de butinage, dues aux changements au 
sein du nid ou dans les conditions de butinage, ressemblent aux décisions de groupe, bien que chaque individu réagisse à un ensemble de stimuli. Les variations dans les seuils de réponse à des stimuli qui déclenchent un comportement donné, entraînent des modifications dans le comportement et la division du travail.

Cette synthèse porte sur les relations entre réponses sensorielles des abeilles et comportement. La sensibilité sensorielle limite la plasticité comportementale et influence les décisions collectives de la colonie. Nous considérons la récolte de pollen, de nectar et d'eau et montrons que la différence dans la sensibilité des abeilles au saccharose est corrélée aux divers types de comportements, ce qui corrobore le modèle des seuils de réponse pour la division du travail. Nous montrons également que dans une colonie d'abeilles la répartition des butineuses entre diverses tâches données peut s'expliquer par une différence de sensibilité aux stimuli relatifs à la tâche. Les hypothèses sur la pertinence de ces différences de sensibilité pour le comportement sont discutées.

Les décisions collectives au sein d'une colonie sont basées sur des différences individuelles de comportement. En analysant les mécanismes de décisions individuelles nous pouvons peut-être déduire des règles valables pour l'ensemble du groupe. Mais en même temps le comportement individuel peut être contrôlé et modulé par les décisions collectives, alors que le degré de plasticité collective est lié à la plasticité individuelle. Nous pensons que l'analyse des comportements individuels et sa modulation par les décisions collectives sont un moyen pour débrouiller les mécanismes complexes de rétroaction entre les comportements des individus, des sous-groupes d'abeilles et de la colonie.

\section{sensibilité au saccharose / plasticité comporte- mentale / décision collective / butinage / seuil de réaction}

\footnotetext{
Zusammenfassung - Zuckerwasserreaktion und Verhaltensplastizität in Honigbienen (Apis mellifera). Die Arbeitsteilung in einer Kolonie von Honigbienen ist ein komplexer Prozess, der sowohl das kontinuierliche Ausführen einer Tätigkeit verlangt, was zu Spezialisierung und großer Professionalität führt, als auch Plastizität in einer sich ständig ändernden Umwelt erfordert. Änderungen im kollektiven Sammelverhalten der Bienen wegen sich ändernder Situationen im Stock oder in den Sammelbedingungen ähneln Gruppenentscheidungen, obwohl jedes Tier individuell auf eine Reihe von Reizen reagiert. Änderungen in den Reaktionsschwellen für Reize, die bestimmte Verhaltensweisen auslösen, führen zu Änderungen des Verhaltens und zu Arbeitsteilung. Die Modulation von Reizen und/oder von sensorischen Antworten kann zu scheinbar koordinierten Verhaltensänderungen der Gruppe führen.
}

Dieser Übersichtsartikel behandelt die Beziehung zwischen sensorischen Antworten und dem Verhalten von Bienen. Die sensorische Empfindlichkeit einer Biene begrenzt deren Plastizität im Sammelverhalten und beeinflusst kollektive Entscheidungen der Kolonie. Wir diskutieren das Sammeln von Pollen, Nektar und Wasser und zeigen, dass Unterschiede in der Zuckerwasserempfindlichkeit von Bienen mit verschiedenen Verhaltensweisen korrelieren. Diese Befunde unterstützen das Reaktionsschwellenmodell der Arbeitsteilung. Wir zeigen außerdem, dass in einer Honigbienen-Kolonie die Zuordnung von Sammlerinnen zu bestimmten Sammelaufgaben mit unterschiedlichen Empfindlichkeiten für Stimuli erklärt werden kann, die in Bezug $\mathrm{zu}$ der Sammelaufgabe stehen. Hypothesen zur Verhaltensrelevanz dieser Unterschiede in der Empfindlichkeit werden diskutiert.

Kollektive Entscheidungen innerhalb einer Kolonie basieren auf individuellen Verhaltensentscheidungen. Durch die Analyse der Mechanismen von individuellen Entscheidungen können wir möglicherweise Regeln ableiten, die auch für die gesamte Gruppe gelten. Individuelles Verhalten wird andererseits aber auch von kollektiven Entscheidungen bestimmt werden, während gleichzeitig der Grad der kollektiven Verhaltensplastizität von der individuellen Plastizität abhängt. Wir glauben, dass die Analyse von individuellem Verhalten und seiner Modulation durch kollektive Entscheidungen ein Weg ist, die komplexen Rückkopplungsmechanismen im Verhalten zwischen Individuen, Untergruppen von Bienen und der Kolonie aufzuklären.

\section{Apis mellifera / Zuckerwasserreaktion / Arbeits- teilung / Gruppenentscheidungen}

\section{REFERENCES}

Arathi H.S., Spivak M. (2001) Influence of colony genotypic composition on the performance of hygienic behaviour in the honeybee, Apis mellifera L., Anim. Behav. 62, 57-66.

Barker R.L. (1971) The influence of food inside the hive on pollen collection by a honeybee colony, $\mathrm{J}$ Apic. Res. 10, 23-26.

Barker R.J., Lehner Y. (1974) Acceptance and sustenance value of naturally occurring sugars fed to newly emerged adult workers of honey bees (Apis mellifera L.), J. Exp. Zool. 187, 277-286.

Barron A.B., Schulz D.J., Robinson G.E. (2002) Octopamine modulates responsiveness to foraging-related stimuli in honey bees (Apis mellifera), J. Comp. Physiol. A 188, 603-610.

Beshers S.N., Fewell J.H. (2001) Models of division of labor in social insects, Annu. Rev. Entomol. 46, 413-440.

Beutler R. (1935) Neue Untersuchungen über den Zuckergehalt des Blütennektars, Leipzig. Bienenztg. 271-273. 
Bitterman M.E. (1996) Comparative analysis of learning in honeybees, Anim. Learn. Behav. 24, 123-141.

Bonabeau E., Theraulaz G., Deneubourg J.L. (1996) Quantitative study of the fixed threshold model for the regulation of division of labour in insect societies, Proc. R. Soc. London B 263, 15651569.

Calderone N.W., Page R.E. Jr. (1988) Genotypic variability in age polyethism and task specialization in the honey bee (Apis mellifera), Behav. Ecol. Sociobiol. 22, 17-25.

Corbet S.A. (2003) Nectar sugar content: estimating standing crop and secretion rate in the field, Apidologie 34, 1-10.

Couvillon P.A., Nagrampa J.A., Bitterman M.E. (1994) Learning in honeybees (Apis mellifera) as a function of sucrose concentration: analysis of the retrospective effect, J. Comp. Psychol. 108, 274-281.

Dreller C., Tarpy D.R. (2000) Perception of the pollen need by foragers in a honeybee colony, Anim. Behav. 59, 91-96.

Dreller C., Page R.E. Jr., Fondrk M.K. (1999) Regulation of pollen foraging in honeybee colonies: effects of young brood, stored pollen, and empty space, Behav. Ecol. Sociobiol. 45, 227-233.

Eckert C.D., Winston M.L., Ydenberg R.C. (1994). The relationship between population size, amount of brood, and individual foraging behavior in the honey bee, Apis mellifera L., Oecologia 97, 248255.

Farina W.M., Núñez J.A. (1991) Trophallaxis in the honeybee, Apis mellifera (L.) as related to the profitability of food sources, Anim. Behav. 42, 389-394.

Fewell J.H., Page R.E. Jr. (2000) Colony-level selection effects on individual and colony foraging task performance in honey bees, Apis mellifera L., Behav. Ecol. Sociobiol. 48, 173181.

Fewell J.H., Winston M.L. (1992) Colony state and regulation of pollen foraging in the honey bee, Apis mellifera, Behav. Ecol. Sociobiol. 30, 387393.

Free J.B. (1987) Pheromones of social bees, Chapman and Hall, London.

Frisch K. von (1927) Versuche über den Geschmacksinn der Bienen, Naturwissenschaften 14, 1-20.

Frisch K. von (1965) Tanzsprache und Orientierung der Bienen. Springer-Verlag, Berlin, Heidelberg, New York.

Greggers U., Kuettner A., Mauelshagen J., Menzel R. (1993) Optimization of honeybees with balanced US-qualities, in: Elsner N., Heisenberg M. (Eds.), Gene-Brain-Behavior, Proceedings of the $21 \mathrm{st}$ Göttingen Neurobiology Conference, Stuttgart, Georg Thieme Verlag, p. 841.

Hunt G.J., Page R.E. Jr., Fondrk M.K., Dullum C.J. (1995) Major quantitative trait loci affecting honey bee foraging behavior, Genetics 141, 1537-1545.
Kunze G. (1933) Einige Versuche über den Geschmackssinn der Honigbiene, Zool. Jahrb. Abt. Allg. Zool. Physiol. Tiere 52, 465-512.

Laloi D., Sandoz J.C., Picard-Nizou A.L., Marchesi A., Pouvreau A., Taséi J.N., Poppy G., PhamDelègue M.H. (1999) Olfactory conditioning of the proboscis extension in bumble bees, Entomol. Exp. Appl. 90, 123-129.

Loo S.K., Bitterman M.E. (1992) Learning in honeybees (Apis mellifera) as a function of sucrose concentration, J. Comp. Psychol. 106, 29-36.

Marshall J. (1935) On the sensitivity of the chemoreceptors on the antenna and fore-tarsus of the honey-bee, Apis mellifica L., J. Exp. Biol. 12, 17-26.

Menzel R., Müller U. (1996) Learning and memory in honeybees: from behavior to neural substrates, Rev. Neurosci. 19, 379-404.

Núñez J.A. (1966) Quantitative Beziehungen zwischen den Eigenschaften von Futterquellen und dem Verhalten von Sammelbienen, Z. Vergl. Physiol. 53, 142-164.

Núñez J.A., Giurfa M. (1996) Motivation and regulation of honey bee foraging, Bee World 77, 182-196.

Page R.E. Jr., Erber J. (2002) Levels of behavioral organization and the evolution of division of labor, Naturwissenschaften 89, 91-106.

Page R.E. Jr., Fondrk M.K. (1995) The effects of colony-level selection on the social organization of honey bee (Apis mellifera L.) colonies: colonylevel components of pollen hoarding, Behav. Ecol. Sociobiol. 36, 135-144.

Page R.E., Mitchell S.D. (1998) Self organization and the evolution of division of labor, Apidologie 29, 171-190.

Page R.E. Jr., Erber J., Fondrk M.K. (1998) The effect of genotype on response thresholds to sucrose and foraging behavior of honey bees ( Apis mellifera L.), J. Comp. Physiol. A 182, 489-500.

Page R.E. Jr., Fondrk M.K., Hunt G.J., GuzmánNovoa E., Humphries M.A., Nguyen K., Green A.S. (2000) Genetic dissection of honeybee (Apis mellifera L.) foraging behavior, J. Hered. 91, 474-479.

Pankiw T. (2003) Directional change in a suite of foraging behaviors in tropical and temperate evolved honey bees (Apis mellifera L.), Behav. Ecol. Sociobiol. 54, 458-464.

Pankiw T., Page R.E. Jr. (1999) The effect of genotype, age, sex, and caste on response thresholds to sucrose and foraging behavior of honey bees (Apis mellifera L.), J. Comp. Physiol. A 185, 207-213.

Pankiw T., Page R.E. Jr. (2000) Response thresholds to sucrose predict foraging behavior in the honey bee (Apis mellifera L.), Behav. Ecol. Sociobiol. 47, 265-267.

Pankiw T., Page R.E. Jr. (2001) Brood pheromone modulates honeybee (Apis mellifera L.) sucrose response thresholds, Behav. Ecol. Sociobiol. 49, 206-213. 
Pankiw T., Rubink W.L. (2002) Pollen foraging response to brood pheromone by Africanized and European honey bees (Apis mellifera L.), Ann Entomol. Soc. Am. 95, 761-767.

Pankiw T., Page R.E. Jr., Fondrk M.K. (1998) Brood pheromone stimulates pollen foraging in honey bees (Apis mellifera), Behav. Ecol. Sociobiol. 44, 193-198.

Pankiw T., Waddington K.D., Page R.E. Jr. (2001) Modulation of sucrose response thresholds in honey bees (Apis mellifera L.): influence of genotype, feeding and foraging experience, $\mathrm{J}$. Comp. Physiol. A 187, 293-301.

Pankiw T., Nelson M., Page R.E. Jr., Fondrk M.K. (2004) The communal crop: modulation of sucrose response thresholds of pre-foraging honey bees with incoming nectar quality, Behav. Ecol. Sociobiol. 55, 286-292, DOI: 10.1007/ s00265-003-0714-0.

Pflumm W. (1969) Correlations between preening behaviour and foraging tendency in the honeybee, Z. Vergl. Physiol. 64, 1-36.

Raveret-Richter M., Waddington K.D. (1993) Past foraging experience influences honey bee dance behaviour, Anim. Behav. 46, 123-128.

Robinson G.E. (1992) Regulation of division of labor in insect societies, Annu. Rev. Entomol. 37, 637665.

Robinson G.E., Page R.E. Jr. (1989) Genetic basis for division of labor in an insect society, in: Breed M.D., Page R.E. Jr. (Eds.), The genetics of social evolution, Boulder, West view press, pp. 61-81.

Roces F., Blatt J. (1999) Haemolymph sugars and the control of the proventriculus in the honey bee Apis mellifera, J. Insect Physiol. 45, 221-229.

Scheiner R., Erber J., Page R.E. Jr. (1999) Tactile learning and the individual evaluation of the reward in honey bees (Apis mellifera L.), J. Comp. Physiol. A 185, 1-10.

Scheiner R., Page R.E. Jr., Erber J. (2001a) Responsiveness to sucrose affects tactile and olfactory learning in preforaging honey bees of two genetic strains, Behav. Brain Res. 120, 6773.

Scheiner R., Page R.E. Jr., Erber J. (2001b) The effects of genotype, foraging role, and sucrose responsiveness on the tactile learning performance of honey bees (Apis mellifera L.), Neurobiol. Learn. Mem. 76, 138-150.

Scheiner R., Weiß A., Malun D., Erber J. (2001c) Learning in honey bees with brain lesions: how partial mushroom-body ablations affect sucrose responsiveness and tactile learning, Anim. Cogn. 4, 227-235.

Scheiner R., Plückhahn S., Öney B., Blenau W. Erber J. (2002) Behavioural pharmacology of octopamine, tyramine and dopamine in honey bees, Behav. Brain Res. 136, 545-553.

Scheiner R., Barnert M., Erber J. (2003a) Variation in water and sucrose responsiveness during the foraging season affects proboscis extension learning in honey bees, Apidologie 34, 67-72.

Scheiner R., Müller U., Heimburger S., Erber J. (2003b) Activity of protein kianse A and gustatory responsiveness in the honey bee (Apis mellifera L.), J. Comp. Physiol. A 189, 427-434.

Schmid-Hempel P., Kacelnik A., Houston A.I. (1985) Honeybees maximize efficiency by not filling their crop, Behav. Ecol. Sociobiol. 17, 61-66.

Seeley T.D. (1995) The wisdom of the hive. Harvard University Press, Cambridge Mass, London.

Smith B.H. (1997) An analysis of blocking in binary odorant mixtures: An increase but not a decrease in intensity of reinforcement produces unblocking, Behav. Neurosci. 111, 57-69.

Tezze A.A., Farina W.M. (1999) Trophallaxis in the honeybee, Apis mellifera: the interaction between viscosity and sucrose concentration of the transferred solution, Anim. Behav. 57, 13191326.

Theraulaz G., Bonabeau E., Deneubourg J.L. (1998) Response threshold reinforcement and division of labour in insect societies, Proc. R. Soc. London B 265, 327-332.

Waddington K.D. (1997) Foraging behavior of nectarivores and pollen collectors, Proc. 7th Int Symp. on Pollination Lethbridge, Canada, pp. 175-191.

Waddington K.D., Nelson C.M., Page R.E. Jr. (1998) Effects of pollen quality and genotype on the dance of foraging honey bees, Anim. Behav. 56, 35-39. 